\title{
Mechanochemical Synthesis of a Cocrystal of Two Supramolecular Hydrogen-Bonded Aggregates of 1,3,6,8-Tetraazatricyclo[4.3.1.13,8]undecane (TATU) with 4-tert-Butylphenol Bearing Different Hydrogen Bonding Interactions
}

\author{
Augusto Rivera ${ }^{1, *}$, Jicli José Rojas ${ }^{1}$, Jaime Ríos-Motta ${ }^{1}$ and Michael Bolte 2 (i) \\ 1 Departamento de Química, Facultad de Ciencias, Universidad Nacional de Colombia, Sede Bogotá, \\ Carrera 30 No. 45-03, Bogotá, Código Postal 111321, Colombia; rsjiclij@unal.edu.co (J.J.R.); \\ jariosmo@unal.edu.co (J.R.-M.) \\ 2 Institut für Anorganische Chemie, J. W. Goethe-Universität Frankfurt, Max-von Laue-Str., 7, \\ 60438 Frankfurt/Main, Germany; bolte@chemie.uni-frankfurt.de \\ * Correspondence: ariverau@unal.edu.co; Tel.: +57-1-316-5000
}

Received: 2 July 2018; Accepted: 20 July 2018; Published: 30 July 2018

\begin{abstract}
The synthesis and single crystal structure of a new cocrystal, which is composed of OHphenolic...OHphenolic...Naminalic supramolecular heterosynthons assembled from 4-tert-butylphenol and the macrocyclic aminal TATU, is presented. This cocrystal was prepared by solvent-free assisted grinding, which is a commonly used mechanochemical method. Crystal structure, supramolecular assembly through hydrogen bonding interactions as well as the physical and spectroscopic properties of the title cocrystal are presented in this paper.
\end{abstract}

Keywords: supramolecular chemistry; crystal engineering; cocrystals; hydrogen bonds; noncovalent interactions; aminal structure

\section{Introduction}

Noncovalent interactions, such as electrostatic forces, H-bonds, halogen bonds, $\mathrm{CH}-\pi$, $\pi-\pi$ stacking, cation $-\pi$, anion $-\pi$, lone pair $-\pi$ associations and other weak forces, play significant roles in a variety of fields, including molecular recognition, host-guest chemistry, crystal engineering, supramolecular chemistry, biochemistry, pharmaceutical chemistry, and materials science [1,2]. Of these interactions, hydrogen bond interactions are the most powerful supramolecular interactions through which many topology structures, such as an infinite 1-D chain, 1-D tapes, 2-D sheet, and 3-D networks, can be assembled [3,4]. Cocrystallization in crystal engineering has emerged as an alternative route, which has the potential to control important physicochemical properties [5,6]. The design of cocrystals involves the formation of supramolecular heterosynthons of certain functional groups, such as carboxylic acid-aromatic nitrogen, carboxylic acid-amide and alcohol-pyridine, which are noncovalently bonded [7]. We use phenols as cocrystal coformers due to their ability to form $\mathrm{O}-\mathrm{H} \cdots \mathrm{N}$ hydrogen bond interactions with macrocyclic aminals. These can provide more complex noncovalent associations when they are associated with aminals and they represent an even more prevalent functional group compared to carboxylic acids. Mechanochemistry is concerned with chemical transformations induced by mechanical means, such as compression, shear or friction. Many methods and techniques are used for the preparation of cocrystals. Nowadays, the solid-state grinding, which is also known as mechanochemical synthesis, has developed as an interesting alternate method/technique for cocrystal synthesis [7-10]. We previously reported [11-13] that 
grinding a 1:1 mixture of 1,3,6,8-tetraazatricyclo[4.3.1.1 phenols (4-nitrophenol, 4-chlorophenol and 4-chloro-3,5-dimethylphenol) at room temperature for 15 min affords phenol-aminal 2/1 cocrystals in excellent yields, which have been assembled through hydrogen-bonding interactions. Furthermore, no side products are formed in the reaction mixture. In the present study, we focus upon hydrogen-bonded cocrystals, which involves aminalic nitrogen moieties and 4-tert-butylphenol. This cocrystal was obtained with a mechanochemical synthesis approach, before being characterized by single crystal X-ray diffraction, FT-IR spectroscopy and NMR. The corresponding crystal structure of the 1:2 adduct is given in Figure 1.

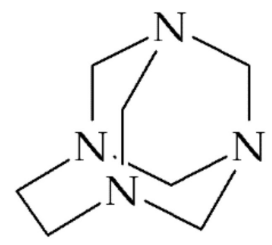

1

Scheme 1. The structure of 1,3,6,8-tetraazatricyclo[4.3.1.1 $\left.1^{3,8}\right]$ undecane (TATU, 1).

\section{Materials and Methods}

The compound 1,3,6,8-tetraazatricyclo[4.3.1.1 $\left.{ }^{3,8}\right]$ undecane (TATU, 1) was synthesized as described in the literature [14]. The melting point was determined with an electrothermal apparatus (Cole-Parmer Lab Apparatus, Stone, Staffordshire, UK) using an open capillary tube, which was uncorrected. The IR spectrum of this compound was recorded as $\mathrm{KBr}$ pellets at $292 \mathrm{~K}$ on a Thermo Nicolet IS10 spectrophotometer (Thermo Scientific, Madison, WI, USA). The ${ }^{1} \mathrm{H}-\mathrm{NMR}$ and ${ }^{13} \mathrm{C}-\mathrm{NMR}$ spectra were recorded in $\mathrm{CDCl}_{3}$ using a Bruker Avance AV-400 MHz spectrometer (Bruker, Leipzig, Germany) operated at $400.130 \mathrm{MHz}$ for ${ }^{1} \mathrm{H}$ and at $100.634 \mathrm{MHz}$ for ${ }^{13} \mathrm{C}$. The chemical shifts are quoted relative to the TMS peak. Crystals that were suitable for X-ray diffraction were obtained from $n$-hexane upon the slow evaporation of the solvent at room temperature.

\subsection{Preparation of TATU-4TBP Cocrystal}

A mixture of 1,3,6,8-tetraazatricyclo[4.3.1.13,8 undecane (TATU) (154 mg, $1 \mathrm{mmol}$ ) and 4-tert-butylphenol (4TBP) (300 mg, $2 \mathrm{mmol}$ ) was ground in a mortar at room temperature for $15 \mathrm{~min}$ as required to complete the reaction. The mixture was recrystallized from $n$-hexane solution to obtain colorless crystals that are suitable for X-ray analysis, m.p. $=366-368 \mathrm{~K}$. (yield: $76 \%$ ). ${ }^{1} \mathrm{H}-\mathrm{NMR}$ $\left(\mathrm{CDCl}_{3}, 400 \mathrm{MHz}\right) 1.29\left(\mathrm{~s}, 18 \mathrm{H}, \mathrm{CH}_{3}\right), 3.24(\mathrm{~s}, 4 \mathrm{H}), 3.78\left(\mathrm{~d}, 4 \mathrm{H},{ }^{3} \mathrm{~J}=13.6 \mathrm{~Hz}\right), 4.36(\mathrm{~s}, 2 \mathrm{H}), 4.69(\mathrm{~d}, 4 \mathrm{H}$, $\left.{ }^{3} J=13.6 \mathrm{~Hz}\right), 6.72\left(\mathrm{~d}, 4 \mathrm{H},{ }^{3} \mathrm{~J}=8 \mathrm{~Hz}\right), 7.24\left(\mathrm{~d}, 2 \mathrm{H},{ }^{3} J=8.8 \mathrm{~Hz}\right)$. IR (KBr disc): 3240.8, 2957.4, 2550.0, $1258.0 \mathrm{~cm}^{-1}$.

\subsection{X-Ray Analysis}

The X-ray diffraction data were collected on a STOE IPDS II(STOE \& Cie GmbH, Darmstadt, Germany) two-circle-diffractometer equipped with $\mathrm{MoK} \alpha$ radiation $(\lambda=0.71073 \AA$ ) at $173(2) \mathrm{K}$ in the $\omega$ scan mode. Unit cell refinement was conducted using the X-Area software [15]. The structure was solved by direct methods using the SHELX-2016/6 [16]. For the structural refinement [16], the nonhydrogen atoms were treated anisotropically, the hydrogen atoms bonded to $\mathrm{O}$ were refined isotropically and the remaining $\mathrm{H}$ atoms were treated as riding. Crystallographic data have been deposited at the Cambridge Crystallographic Data Centre (CCDC). The copies of the data can be obtained free of charge upon application to the CCDC, 12 Union Road, Cambridge CB2 IEZ, UK. Fax: +44-(0)1223-336033 or e-mail: deposit@ccdc.cam.ac.uk. The CCDC deposition number is 1852317. Selected crystallographic data and details concerning data collection and structure refinement are given in Table 1. 
Table 1. Crystal data and structure refinement for 4TBP-TATU aggregate.

\begin{tabular}{|c|c|}
\hline Compound & Parameters \\
\hline CCDC No. & 1852317 \\
\hline Empirical formula & $\mathrm{C}_{27} \mathrm{H}_{42} \mathrm{~N}_{4} \mathrm{O}_{2}$ \\
\hline Formula weight & 454.64 \\
\hline Temperature & $173(2) \mathrm{K}$ \\
\hline Crystal system & triclinic \\
\hline Space group & $P-1$ \\
\hline Unit cell dimensions & $\begin{array}{c}\mathrm{a}=6.2023(5) \AA, \alpha=89.382(6)^{\circ} \\
\mathrm{b}=11.8765(9) \AA, \beta=86.729(6)^{\circ} \\
\mathrm{c}=86.729(6) \AA, \gamma=87.117(6)^{\circ}\end{array}$ \\
\hline Volume & $2607.8(4) \AA^{3}$ \\
\hline $\mathrm{Z}$ & 4 \\
\hline Calculated density & $1.158 \mathrm{~g} / \mathrm{cm}^{3}$ \\
\hline Absorption coefficient & $0.074 \mathrm{~mm}^{-1}$ \\
\hline $\mathrm{F}(000)$ & 992 \\
\hline Crystal size $\mathrm{mm}^{3}$ & $0.23 \times 0.19 \times 0.15$ \\
\hline$\theta \min / \theta \max /^{\circ}$ & $1.806 / 25.480$ \\
\hline Limiting indices & $-7 \leq \mathrm{h} \leq 7,-14 \leq \mathrm{k} \leq 13,-42 \leq 1 \leq 42$ \\
\hline Reflections collected & 37001 \\
\hline Independent reflections & $37001[R($ int $)=$ ?] \\
\hline Refinement method & Full-matrix least-squares on $F^{2}$ \\
\hline Data/restraints/parameters & $37001 / 0 / 612$ \\
\hline Goodness of fit on $F^{2}$ & 0.896 \\
\hline$R 1 / w R 2[I>2 \sigma(\mathrm{I})]$ & $0.0606 / 0.1476$ \\
\hline$R 1 / w R 2($ all data) & $0.1016 / 0.1632$ \\
\hline Largest diff. peak and hole/e. $\AA^{-1}$ & $0.406 /-0.236$ \\
\hline
\end{tabular}

\section{Results and Discussion}

\subsection{Single Crystal X-Ray Diffraction}

The title adduct forms triclinic crystals (space group $P-1, Z=4$ ), the molecular structure of which is depicted in Figure 1. Two independent hydrogen-bonded adducts, which are labelled as I (left) and II (right), were found in the large complex asymmetric unit. Each adduct is composed of two molecules of 4-tert-butylphenol (4TBP) and one molecule of TATU (see Figure 1 for the labelling scheme). X-ray crystallographic data show small but significant differences in the bond-lengths of the two non-equivalents adducts, which is most unusual in these structures. This is more evident from the geometry of the aminal cage and the hydrogen-bonded supramolecular assemblies.

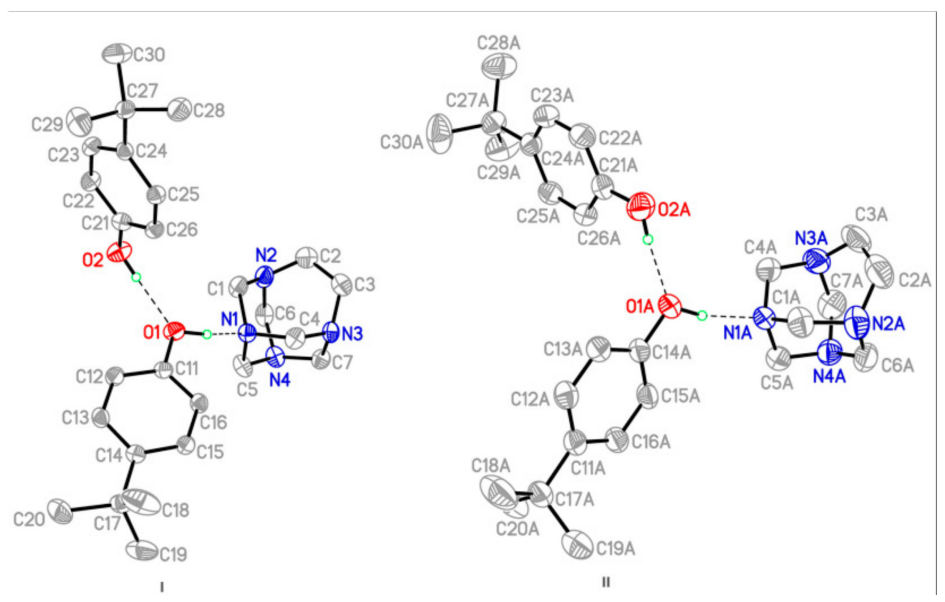

Figure 1. A view of the two independent three-molecule aggregate (I and II) in the asymmetric unit of the title compound with the atom-labelling scheme and 50\% probability displacement ellipsoids, showing the $\mathrm{O}-\mathrm{H} \cdots \mathrm{N}$ and $\mathrm{O}-\mathrm{H} \cdots \mathrm{O}$ hydrogen bond interactions as purple dashed lines. 
The adducts have similar but not identical conformations, which was indicated by the r.m.s. overlay fit of $0.04 \AA$ for the atoms N1, O1 and O2. The main differences include the slightly different twist of the 4-tert-butylphenol molecules and the fact that the TATU molecules are inverted (Figure 2).

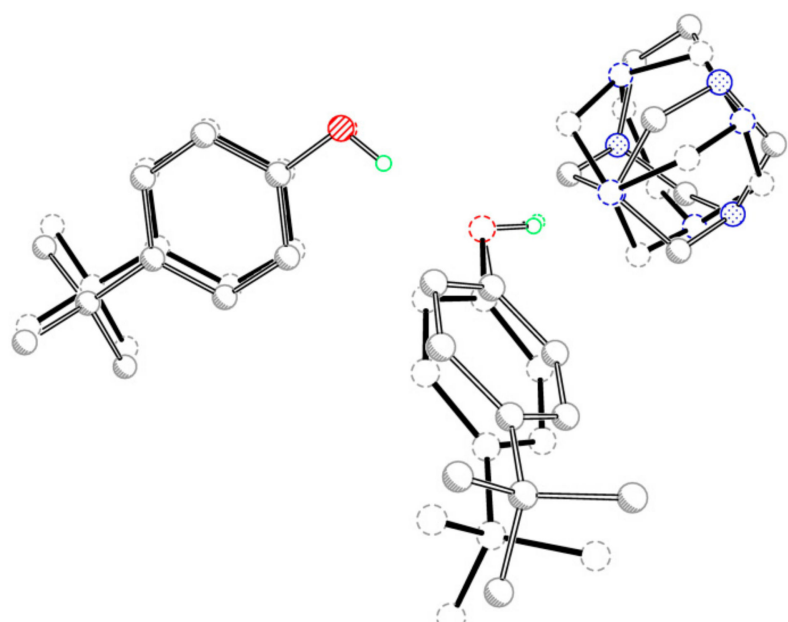

Figure 2. Overlay plot of the two three-molecule aggregates in title compounds (I and II), with the O1, $\mathrm{O} 2$ and $\mathrm{N} 1$ atoms as the common basis.

The two crystallographically independent ternary cocrystal units I and II (Figure 1) display the same type of molecular association. Both consist of hydrogen-bonded three-molecule aggregates in which one of the nitrogen atoms of TATU is hydrogen bonded to the hydroxyl group of 4TBP, which gives rise to the formation of a amine-phenol adduct. In turn, 4TBP is hydrogen bonded to another molecule of 4TBP via the phenol-phenol (diphenol) $\mathrm{O}-\mathrm{H} \cdots \mathrm{O}$ interaction. Despite the rather similar constitutions of I and II and the virtually identical bond lengths and bond angles for the four independent 4TBP molecules (Table 2), the interatomic distances for $\mathrm{N} \cdots \mathrm{H}-\mathrm{O}$ and $\mathrm{O} \cdots \mathrm{H}-\mathrm{O}$ hydrogen bonds were different.

Table 2. Hydrogen bonds for ternary cocrystal units I and II [ $\AA^{\circ}$ and $\left.{ }^{\circ}\right]$.

\begin{tabular}{ccccc}
\hline $\mathbf{D}-\mathbf{H} \cdots \mathbf{A}$ & $\mathrm{d}(\mathbf{D}-\mathbf{H})$ & $\mathbf{d}(\mathbf{D} \cdots \mathbf{A})$ & $\mathbf{d}(\mathbf{D} \cdots \mathbf{A})$ & $\angle$ (DHA) \\
\hline $\mathrm{O}(1)-\mathrm{H}(1) \cdots \mathrm{N}(1)$ & $1.07(5)$ & $1.57(5)$ & $2.630(4)$ & $168(3)$ \\
$\mathrm{O}(2)-\mathrm{H}(2) \cdots \mathrm{O}(1) \# 1$ & $0.86(4)$ & $1.84(4)$ & $2.699(4)$ & $176(4)$ \\
$\mathrm{O}(1 \mathrm{~A})-\mathrm{H}(1 \mathrm{~A}) \cdots \mathrm{N}(1 \mathrm{~A})$ & $0.97(5)$ & $1.71(5)$ & $2.655(4)$ & $164(3)$ \\
$\mathrm{O}(2 \mathrm{~A})-\mathrm{H}(2 \mathrm{~A}) \cdots \mathrm{O}(1 \mathrm{~A})$ & $0.88(4)$ & $1.86(4)$ & $2.736(4)$ & $174(3)$ \\
$\mathrm{C}(1)-\mathrm{H}(1 \mathrm{~B}) \cdots \mathrm{N}(3) \# 2$ & 0.99 & 2.62 & $3.537(5)$ & 153.9 \\
$\mathrm{C}(4)-\mathrm{H}(4 \mathrm{~A}) \cdots \mathrm{O}(2) \# 3$ & 0.99 & 2.44 & $3.307(4)$ & 146.2 \\
$\mathrm{C}(1 \mathrm{~A})-\mathrm{H}(1 \mathrm{~A} 1) \cdots \mathrm{N}(4 \mathrm{~A}) \# 2$ & 0.99 & 2.67 & $3.625(5)$ & 163.0 \\
$\mathrm{C}(5 \mathrm{~A})-\mathrm{H}(5 \mathrm{~A} 2) \cdots \mathrm{O}(2 \mathrm{~A}) \# 4$ & 0.99 & 2.43 & $3.382(4)$ & 160.0 \\
$\mathrm{C}(28)-\mathrm{H}(28 \mathrm{~B}) \cdots \mathrm{Cg} 1 \# 5$ & 0.99 & 2.84 & $3.814(4)$ & 175.0 \\
$\mathrm{C}(29 \mathrm{~A})-\mathrm{H}(29 \mathrm{~F}) \cdot \mathrm{Cg} 2 \# 1$ & 0.99 & 2.81 & $3.785(4)$ & 172.0 \\
$\mathrm{C}(20)-\mathrm{H}(20 \mathrm{~B}) \cdots \mathrm{Cg} 3 \# 6$ & 0.99 & 2.71 & $3.573(5)$ & 148.0 \\
$\mathrm{C}(20 \mathrm{~A})-\mathrm{H}(20 \mathrm{~F}) \cdots \mathrm{C} 2$ 2\#7 & 0.99 & 2.83 & $3.579(4)$ & 134.0 \\
$\mathrm{C}(18 \mathrm{~A})-\mathrm{H}(18 \mathrm{~F}) \cdots \mathrm{Cg} 4 \# 8$ & 0.99 & 2.76 & $3.585(4)$ & 142.0 \\
$\mathrm{C}(2)-\mathrm{H}(2 \mathrm{C}) \cdots \mathrm{Cg} 4 \# 7$ & 0.99 & 2.94 & $3.851(5)$ & 154.0 \\
\hline
\end{tabular}

Symmetry transformations used to generate equivalent atoms: $\# 1 \mathrm{x}, \mathrm{y}+1, \mathrm{z} ; \# 2 \mathrm{x}+1, \mathrm{y}, \mathrm{z} ; \# 3 \mathrm{x}-1, \mathrm{y}-1, \mathrm{z} ; \# 4 \mathrm{x}-$ $1, \mathrm{y}, \mathrm{z} ; \# 5 \mathrm{x}, \mathrm{y}, \mathrm{z} ; \# 6 \mathrm{x}-1, \mathrm{y}-1, \mathrm{z}-1 ; \# 7-\mathrm{x}+1,-\mathrm{y}+1,-\mathrm{z}+1 ; \# 8-\mathrm{x}+2,-\mathrm{y}+1,-\mathrm{z}+2$.

Within the aminal cage structures, the corresponding ethylene bridge shows a considerable variation in their conformations (Table 2 and Figure 2). In particular, the values of the $\mathrm{N}-\mathrm{C}-\mathrm{C}-\mathrm{N}$ torsion angles and the $\mathrm{C}-\mathrm{C}$ bond lengths show variations among these compounds. In complex 
I, they refine to $\mathrm{N}(2)-\mathrm{C}(2)-\mathrm{C}(3)-\mathrm{N}(3)=6.0(6)$ and $\mathrm{C} 2-\mathrm{C} 3=1.508(6) \AA$, while the equivalent data for cocrystal II are N2-C2A-C3A-N3A $=-1.5(6)$ and $\mathrm{C} 2 \mathrm{~A}-\mathrm{C} 3 \mathrm{~A}=1.545$ (6) $\AA$. This allows for the association of these variations with the different patterns of hydrogen bonds involving these structures in I and II. On the other hand, similar to the related structures, the comparison of the $\mathrm{C}-\mathrm{N}$ bond lengths in the title compound with respect to the mean value of $1.469 \AA$ [17] are indicative of the grade of the polarization of the aminal cage structure. In the supramolecular structure of $\mathrm{I}$, the $\mathrm{C}-\mathrm{N}$ bond lengths range from 1.474-1.484 $\AA$, while this is in the range of 1.468-1.481 $\AA$ in the supramolecular structure of I, which indicates that in the crystal structure of aggregate I, the molecules are linked by intermolecular hydrogen bonds that are much shorter than the intermolecular hydrogen bonds in II (see Table 2).

In principle, the crystal packing of the unit-cell contents for I and II are similar. Specifically, the ternary aggregates interlock neatly and are stacked in columns (Figure 3) via two intermolecular $\mathrm{C}-\mathrm{H} \cdots \mathrm{O}$ and $\mathrm{C}-\mathrm{H} \cdots \mathrm{N}$ nonconventional hydrogen-bonding interactions (Table 2), which result in separate $-\mathrm{A}-\mathrm{A}-\mathrm{A}-\mathrm{A}-$ and $-\mathrm{B}-\mathrm{B}-\mathrm{B}-\mathrm{B}-$ columns. Both columns propagate along the a axis and have a $\mathrm{R}_{4}^{4}(10)$ motif in which the adjacent aggregates are related by simple unit-cell translation (Table 2). The partial packing plots of the title cocrystal (Figure 3) illustrate the hydrogen-bonding motifs. However, in complexes I and II, the $\mathrm{C}-\mathrm{H} \cdots \mathrm{N}$ hydrogen bond acceptor and the $\mathrm{C}-\mathrm{H} \cdots \mathrm{O}$ hydrogen bond donor are different. In the complex I, the $\mathrm{R}_{4}^{4}(10)$ motif is formed by $\mathrm{C}-\mathrm{H} \cdots \mathrm{N}$ interactions, involving the $\mathrm{N} 3$ atom attached to the ethylene bridge as a $\mathrm{C}-\mathrm{H} \cdots \mathrm{N}$ acceptor and the neighboring methylene $\mathrm{N} 3-\mathrm{CH}_{2}-\mathrm{N} 1$ as the $\mathrm{C}-\mathrm{H} \cdots \mathrm{O}$ donor. In complex II, the acceptor is the N4A atom for $\mathrm{C}-\mathrm{H} \cdots \mathrm{N}$ interactions and the $\mathrm{N} 4 \mathrm{~A}-\mathrm{CH}_{2}-\mathrm{N} 1 \mathrm{~A}$ group is the $\mathrm{C}-\mathrm{H} \cdots \mathrm{O}$ hydrogen bond donor (Table 2). This bonding mode possibly correlates with the different patterns of hydrogen bonds involving the hydrogen bond acceptor N1 in I and II, which was described above.

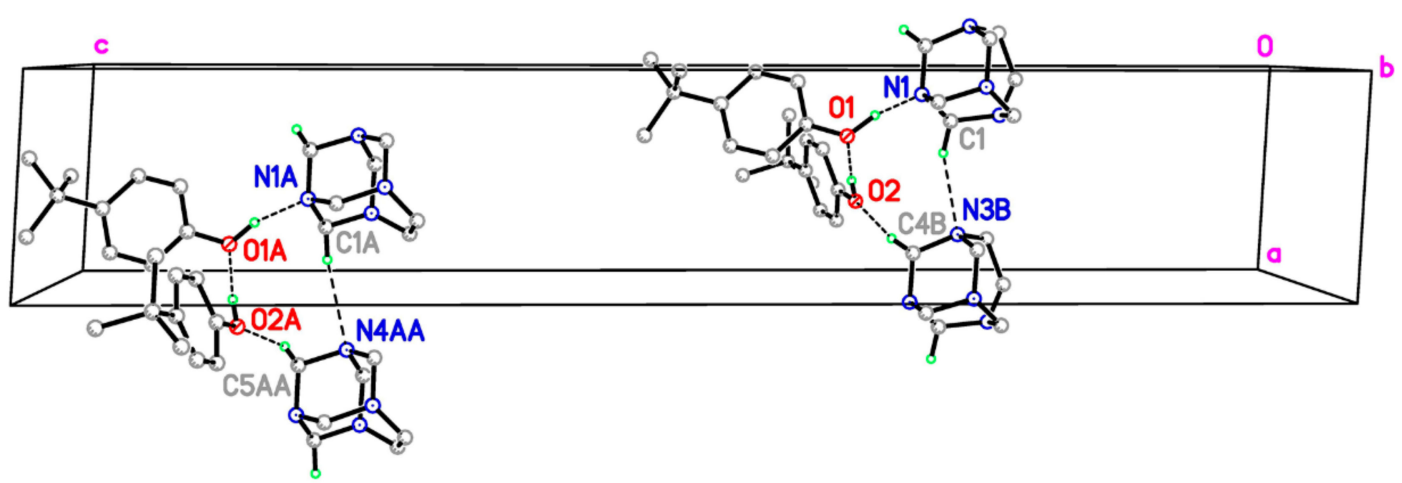

Figure 3. Part of the crystal structure of title compound, showing the formation of ring of graph-set motif $\mathrm{R}_{4}^{4}(10)$ and hydrogen bonded columns along [ $\left[\begin{array}{lll}1 & 0 & 0\end{array}\right]$. These are formed by $\mathrm{C}-\mathrm{H} \cdots \mathrm{O}$ and $\mathrm{C}-\mathrm{H} \cdots \mathrm{N}$ hydrogen-bond interactions. For clarity, $\mathrm{H}$ atoms not involved in the motif have been omitted. Green and purple dashed lines indicate the $\mathrm{O}-\mathrm{H} \cdots \mathrm{N}$ hydrogen bonds and weak $\mathrm{C}-\mathrm{H} \cdots \mathrm{O}$ and $\mathrm{C}-\mathrm{H} \cdots \mathrm{N}$ nonconventional hydrogen bonds, respectively.

Additionally, directional $\mathrm{C}-\mathrm{H} \cdots \pi$ interactions occur, which involve $\mathrm{C}-\mathrm{H}$ bonds from tert-butyl groups joined to $\mathrm{C} 21-\mathrm{C} 26$ or $\mathrm{C} 21 \mathrm{~A}-\mathrm{C} 26 \mathrm{~A}$ benzene rings for cocrystals I and II, respectively, to tert-butylphenol rings (C11-C16, centroid $C g 1$ and $\mathrm{C} 11 \mathrm{~A}-\mathrm{C} 16 \mathrm{~A}$, centroid $\mathrm{Cg} 2)$ from neighboring columns of similar ternary aggregates. The bond angles for $\mathrm{C} 28-\mathrm{H} 28 \mathrm{~B} \cdots C g 1^{\mathrm{i}}$ (symmetry code: $\mathrm{x}, \mathrm{y}$, $\mathrm{z}$ ) and $\mathrm{C} 29 \mathrm{~A}-\mathrm{H} 29 \mathrm{~F} \cdots \mathrm{Cg} 2^{\mathrm{ii}}$ (symmetry code: $\mathrm{x}, \mathrm{y}+1, \mathrm{z}$ ) are $175^{\circ}$ and $172^{\circ}$, respectively, which work together to stabilize the columns and link these columns into separate two-dimensional sheets that lie parallel to $a b$ plane (Figure 4). In addition, the inversion-related sheets of similar ternary cocrystals are connected by weak $\mathrm{C}-\mathrm{H} \cdots \pi$ interactions. In complex $\mathrm{I}$, neighboring inversion-related sheets are stacked onto each other through $\mathrm{C} 20-\mathrm{H} 20 \cdots \mathrm{Cg} 3$ (C21-C26) (see Table 2 and Figure 4). In complex II, the C18A-H18F $\cdots$ Cg $4(\mathrm{C} 21 \mathrm{~A}-\mathrm{C} 26 \mathrm{~A})$ and C20A-H20F $\cdots \mathrm{Cg} 2(\mathrm{C} 11-\mathrm{C} 16) \mathrm{C}-\mathrm{H} \cdots \pi$ interactions (Table 2) join the respective inversion-related sheets. Thus, the formed supramolecular layered architectures of 
I and II are subsequently crosslinked by further weak $\mathrm{C}-\mathrm{H} \cdots \pi$ interactions through $\mathrm{C} 2-\mathrm{H} 2 \mathrm{C} \cdots \mathrm{Cg} 4$, which originates from a hydrogen atom of the ethylene bridge of aminal cage in I interacting with the (C21A-C26A, Cg4) ring in II.

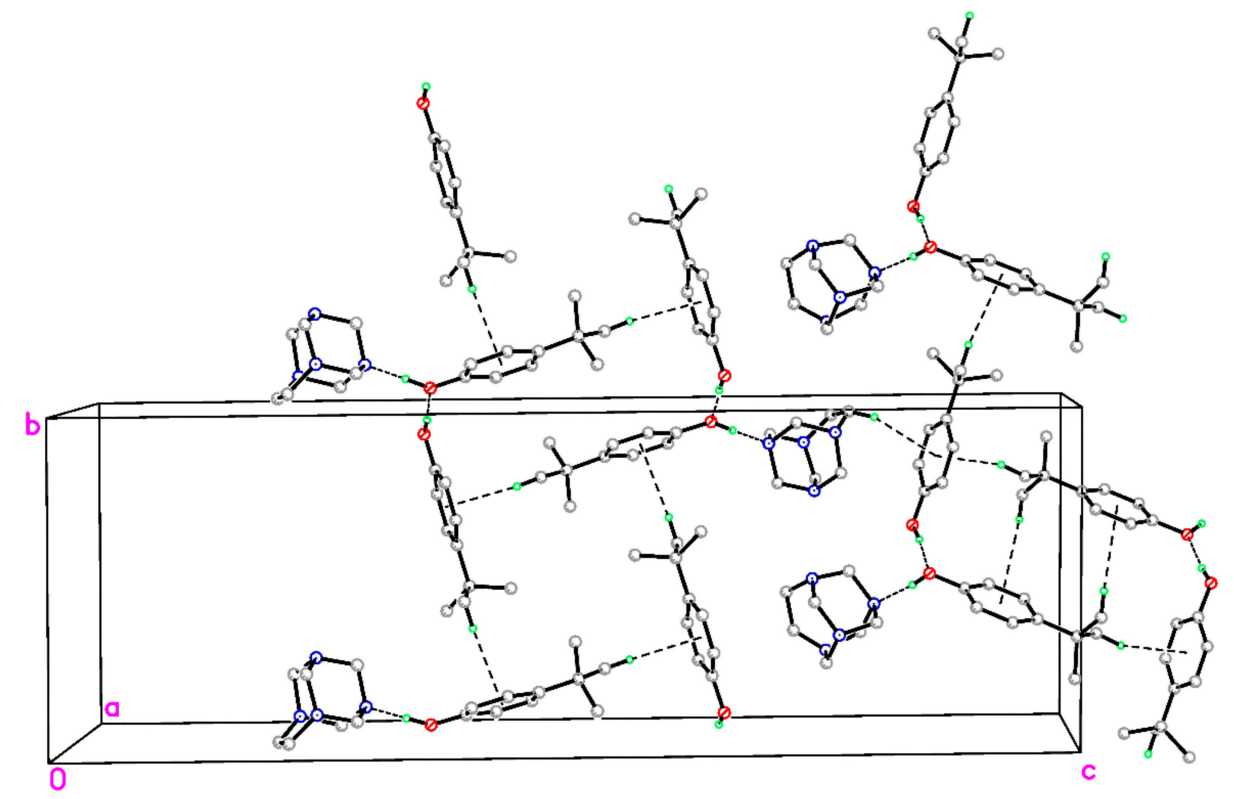

Figure 4. A packing diagram of the title compound showing the $\mathrm{C}-\mathrm{H} \cdots \mathrm{Cg}$ interactions as green dashed lines (Symmetry codes: see Table 2).

We conducted a comparison with the structures found in previous studies for TATU, which forms unique and very stable aggregates with the phenols. In the present work, there is an important difference. For 4-tert-butylphenol, there are two stable aggregates, which are complexes I and II, that contain arrangements in which each TATU unit interacts with two 4-tert-butylphenol molecules due to the formation of a cooperative hydrogen bond network that involves interactions between both hydroxyl groups. These aggregates have similar but not quite identical structures through significantly different supramolecular networks. This difference may partially arise from the participation of the N1 and N1A atoms of the aminal cage structures with different strengths in its $\mathrm{O}-\mathrm{H} \cdots \mathrm{N}$ hydrogen bond interactions. Thus, two stable hydrogen bond aggregates with different proton transfer degrees were shown to exist on the title compound.

\subsection{Spectroscopic Properties}

The structure of the molecular aggregate was confirmed via melting point, ${ }^{1} \mathrm{H} \mathrm{NMR},{ }^{13} \mathrm{C} N \mathrm{NMR}$, and IR analysis. A single set of aliphatic and aromatic resonances can be assigned to the tricyclic tetraamine (TATU) and 4TBP molecules, respectively. This was observed in ${ }^{1} \mathrm{H}$ and ${ }^{13} \mathrm{C}-\mathrm{NMR}$ spectra in $\mathrm{CDCl}_{3}$ of the resulting solid mixtures used in the grinding experiments. Signals corresponding to the aliphatic $\mathrm{C}-\mathrm{H}$ protons in TATU (1) were observed at $\delta$ of 3.20-4.70. A downfield shift of all protons of 1 was observed. The signals corresponding to the aromatic protons of 4TBP were observed at $\delta$ of 6.72 and 7.24, which are largely unaffected. The downfield shift of the TATU protons may arise from the presence of the ternary aggregates species in the solution or it may arise from a simple stacking of isolated molecules. Thus, a question still remains unanswered with regards to the formation of the molecular aggregate. Although solvent evaporation is the most popular way for preparing cocrystals, there are other ways to produce cocrystals, such as solid-state grinding, slurry, solvent drop, supercritical fluid and the use of anti-solvent $[18,19]$. To distinguish between these possibilities, the samples of physical mixture, ground mixture and cocrystal of TATU and 4-TBP with the same molar ratio (1:2) were studied to estimate their association using FT-IR. Thus, $1 \mathrm{mg}$ of each sample of 
physical mixture, ground mixture or intact cocrystal of TATU-4TBP (molar ratio $=1: 2$ ) were separately blended with $100 \mathrm{mg}$ of $\mathrm{KBr}$, before being pressed with an IR spectrophotometric hydraulic press under $400 \mathrm{~kg} / \mathrm{cm}^{2}$ for $15 \mathrm{~s}$ to form a disc.

The FT-IR spectra of the physical mixture, ground mixture and cocrystal of TATU-4TBP with the same molar ratio are shown in Figure 5. The IR spectrum of a physical mixture (Figure 5, black trace) after a simple mixing process shows that the $\mathrm{OH}$ stretching region was not broad, which indicates the weak interactions between TATU and 4-TBP by hydrogen bonding. However, the IR spectra of TATU-4TBP ground mixture prepared by neat co-grinding (Figure 5, red trace) and TATU-4TBP cocrystal prepared by slow solvent evaporation (Figure 5, blue trace) were markedly different from that of the IR spectrum of the TATU-4TBP physical mixture. The phenolic O-H stretching vibrations yielded a broad peak, which were observed in both samples. This is due to hydrogen bonding with an adjacent hydrogen bond acceptor. The appearance of this $\mathrm{O}-\mathrm{H}$ stretching vibration was due to the cocrystal formation via intermolecular interaction between TATU and 4TBP.

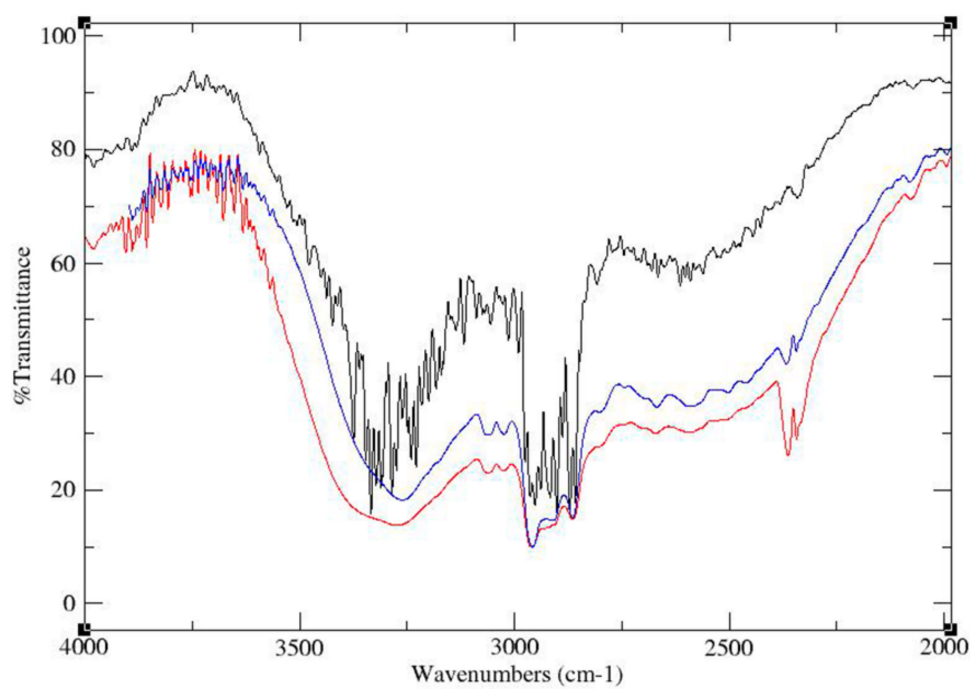

Figure 5. FT-IR spectra of physical mixture (black trace), ground mixture (red trace) and cocrystal (blue trace) of TATU-4TBP.

In conclusion, these results demonstrate that in the solid state, there is a mix of two neutral 4TBP-TATU three molecular synthons, which coexist through $\mathrm{O}-\mathrm{H} \cdots \mathrm{O}-\mathrm{H} \cdots \mathrm{N}$ hydrogen bonds. These were distinguished by the location of the hydroxyl protons in the solid state. From the results of FT-IR and NMR spectra, the ground mixture and solvent evaporated sample of TATU-4TBP were evidenced to be a cocrystal. Thus, the cocrystal was first produced by solid-state grinding.

Author Contributions: A.R. conceived and designed the experiments; J.J.R. performed the experiments; M.B. collected X-ray data and solved the X-ray structure; J.R.-M. wrote the paper.

Funding: This research was funded by Dirección de Investigaciones, Sede Bogotá (DIB) de la Universidad Nacional de Colombia (Grant No. 35816).

Acknowledgments: J.J.R. thanks COLCIENCIAS for a fellowship.

Conflicts of Interest: The authors declare no conflicts of interest.

\section{References}

1. Gao, X.; Li, X.; Jin, S.; Hu, K.; Guo, J.; Guo, M.; Xu, W.; Wang, D. Hydrogen bonded 1D-3D supramolecular structures from Benzylamine and organic acidic components. J. Mol. Struct. 2018, 1155, 39-50. [CrossRef]

2. Aakeröy, C.B.; Perera, M.D. Supramolecular Assembly and Solid State Chemistry. In Engineering Crystallography: From Molecule to Crystal to Functional Form; NATO Science for Peace and Security Series 
A: Chemistry and Biology, Part F1; Roberts, K.J., Docherty, R., Tamura, R., Eds.; Springer: Dordrecht, The Netherlands, 2017; pp. 35-44. ISBN 9789402411171.

3. Rajkumar, M.; Muthuraja, P.; Dhandapani, M.; Chandramohan, A. Supramolecular network through $\mathrm{N}-\mathrm{H} \cdots \mathrm{O}, \mathrm{O}-\mathrm{H} \cdots \mathrm{O}$ and $\mathrm{C}-\mathrm{H} \cdots \mathrm{O}$ hydrogen bonding interaction and density functional theory studies of 4-methylanilinium-3-carboxy-4-hydroxybenzenesulphonate crystal. J. Mol. Struct. 2018, 1153, 192-201. [CrossRef]

4. Thakuria, R.; Sarma, B.; Nangia, A. 7.03-Hydrogen Bonding in Molecular Crystals. In Reference Module in Chemistry, Molecular Sciences and Chemical Engineering. Comprehensive Supramolecular Chemistry II; Atwood, J.L., Ed.; Elsevier: Oxford, UK, 2017; pp. 25-48. ISBN 9780128031995.

5. Abidi, S.S.A.; Azim, Y.; Gupta, A.K.; Pradeep, C.P. Mechanochemical synthesis and structural characterization of three novel cocrystals of dimethylglyoxime with N-heterocyclic aromatic compounds and acetamide. J. Mol. Struct. 2017, 1150, 103-111. [CrossRef]

6. Berry, D.J.; Steed, J.W. Pharmaceutical cocrystals, salts and multicomponent systems; intermolecular interactions and property based design. Adv. Drug Deliv. Rev. 2017, 117, 3-24. [CrossRef] [PubMed]

7. Douroumis, D.; Ross, S.A.; Nokhodchi, A. Advanced methodologies for cocrystal synthesis. Adv. Drug Deliv. Rev. 2017, 117, 178-195. [CrossRef] [PubMed]

8. Magaña-Vergara, N.E.; Cruz-Cruz, P.; Peraza-Campos, A.L.; Martínez-Martínez, F.J.; González-González, J.S. Mechanochemical Synthesis and Crystal Structure of the Lidocaine-Phloroglucinol Hydrate 1:1:1 Complex. Crystals 2018, 8, 130. [CrossRef]

9. Friščić, T. Supramolecular concepts and new techniques in mechanochemistry: Cocrystals, cages, rotaxanes, open metal-organic frameworks. Chem. Soc. Rev. 2012, 41, 3493-3510. [CrossRef] [PubMed]

10. Braga, D.; Maini, L.; Grepioni, F. Mechanochemical preparation of cocrystals. Chem. Soc. Rev. 2013, 42, 7638-7648. [CrossRef] [PubMed]

11. Rivera, A.; Osorio, H.J.; Uribe, J.M.; Ríos-Motta, J.; Bolte, M. Crystal structure of the 1,3,6,8-tetraazatricyclo[4.3.1.1 $1^{3,8}$ undecane (TATU)-4-nitrophenol (1/2) adduct: The role of anomeric effect in the formation of a second hydrogen-bond interaction. Acta Cryst. E 2015, 71, 1356-1360. [CrossRef] [PubMed]

12. Rivera, A.; Rojas, J.J.; Osorio, H.J.; Rios-Motta, J.; Bolte, M. Crystal structure of the 1:2 cocrystal of 1,3,6,8-tetraazatricyclo[4.3.1.1 $1^{3,8}$ undecane (TATU) and 4-chlorophenol (1/2). Acta Cryst. E 2016, 72, 1648-1650. [CrossRef] [PubMed]

13. Rivera, A.; Rojas, J.J.; Sadat-Bernal, J.; Rios-Motta, J.; Bolte, M. Mechanochemical synthesis and crystal structure of a 1:2 cocrystal of 1,3,6,8-tetraazatricyclo-[4.3.1.1 $\left.1^{3,8}\right]$ undecane (TATU) and 4-chloro-3,5-dimethylphenol. Acta Cryst. E 2016, 72, 1651-1653. [CrossRef] [PubMed]

14. Rivera, A.; Núñez, M.E.; Morales-Ríos, M.S.; Joseph-Nathan, P. Preparation of cage amine 1,3,6,8-tetraazatricyclo[4.3.1.1 ${ }^{3,8}$ ] undecane. Tetrahedron Lett. 2004, 45, 7563-7565. [CrossRef]

15. Stoe \& Cie. X-Area Diffractometer Control Software; Stoe \& Cie: Darmstadt, Germany, 2001.

16. Sheldrick, G.M. Crystal structure refinement with SHELXL. Acta Cryst. C 2015, 71, 3-8. [CrossRef] [PubMed]

17. Allen, F.H.; Kennard, O.; Watson, D.G.; Brammer, L.; Orpen, A.G.; Taylor, R. Tables of bond lengths determined by X-ray and neutron diffraction. Part 1. Bond lengths in organic compounds. J. Chem. Soc. Perkin Trans. 2 1987, S1-S19. [CrossRef]

18. Chadha, R.; Bhalla, Y.; Vashisht, M.K.; Chadha, K. Recrystallization in Materials Processing; Intech: Vienna, Austria, 2015; pp. 173-174.

19. An, J.-H.; Lim, C.; Ryu, H.C.; Kim, J.S.; Kim, H.M.; Kiyonga, A.N.; Park, M.; Suh, Y.-G.; Park, G.H.; Jung, K. Structural characterization of Febuxostat/l-Pyroglutamic acid cocrystal using solid-state ${ }^{13} \mathrm{C}-\mathrm{NMR}$ and investigational study of its water solubility. Crystals 2017, 7, 365. [CrossRef]

(C) 2018 by the authors. Licensee MDPI, Basel, Switzerland. This article is an open access article distributed under the terms and conditions of the Creative Commons Attribution (CC BY) license (http://creativecommons.org/licenses/by/4.0/). 